\title{
COVID-19, Nursing, Pediatrics and Measuring Religion and Health
}

\author{
Lindsay B. Carey ${ }^{1}$
}

Accepted: 26 December 2020 / Published online: 9 January 2021

(c) The Author(s), under exclusive licence to Springer Science+Business Media, LLC part of Springer Nature 2021

\section{Introduction}

This first issue for 2021 of the Journal of Religion and Health (JORH 2021) commences with a number of articles about the ongoing pandemic and the international challenge of COVID-19, which continues to ravage many countries around the world as we await access to the various vaccines in production. Given the prominent role and demanding work undertaken by nurses, it seems appropriate that another theme in this issue considers various research relating to the nursing profession. The health and well-being of our next generation are also fundamental, as reflected by the numerous articles in this issue undertaking research relating to pediatrics. Finally, this issue concludes with articles concerned about measuring the association between religion and health.

\section{COVID-19}

Since the initial JORH COVID-19 special issue (JORH 2020a) and the subsequent JORH issue which also noted the impact of COVID-19 (JORH 2020b), the number of publications concerning COVID-19 have reached exponential levels across a broad range of clinical and public health journals. SCOPUS, the largest abstract and citation database of peer reviewed literature, records that approximately 80,000 refereed journal articles were published concerning COVID-19 during 2020 (SCOPUS 2020); the top ten research producing nations being the USA, China, UK, Italy, India, Spain, Canada, Germany, France and Australia (respectively). This JORH issue (JORH 2020a) carries additional COVID-19 articles, which consider contrasting religious and secular perspectives about COVID-19 and related vaccinations, as well as the community impact and responses to COVID-19 internationally (e.g., New Zealand, Palestine, Jordan and Jerusalem). As noted in the previous editorial,

Lindsay B. Carey

Lindsay.Carey@1atrobe.edu.au

1 Palliative Care Unit, Department of Public Health, La Trobe University, Melbourne, Australia 
irrespective of a vaccine, COVID-19 looks to 'dominate both health, economic, and geopolitical multipolar issues for many months' (Carey 2020). There are more COVID-19 articles in process for subsequent JORH issues.

\section{Nursing}

Over the last decade, various international survey polls have indicated that nurses are repeatedly voted in the top 10 of the most highly regarded professionals; in some countries, (e.g., the USA and AU) nurses have successively achieved the highest status (Reinhart 2020; Morgan 2017). The reasons for this vary, but include such factors as: trust and rapport with patients, the provision of bio-psycho-social-spiritual holistic care, being proficient patient advocates, having a pride and dedication with regard to the quality of their work, and helping patients to develop hope during traumatic times. This issue of JORH considers the cultural, intercultural and transcultural sensitivity of nurses, as well as their perceived empathy, their religious/ spiritual perspective and orientation, and their attitudes and practices concerning patient confidentiality, dying with dignity, and death-all important qualities, but particularly pertinent during COVID-19.

\section{Pediatrics}

The discipline of pediatrics has long been an ongoing focus for those responsible for the religious and spiritual well-being of children and adolescents, as well as the support and education necessary for parents and clinical caregivers (Nash et al. 2015; Grossoehme et al. 2007). This issue of JORH explores religious and spiritual factors commencing with infertility, then artificial insemination, surrogacy, pregnancy, abortion, reproductive loss, depression, existential meaning-making from giving birth, neonatal parental anxiety, breastfeeding, child chronic illnesses (i.e., cancer, phenylketonuria), religiosity, death, dying, mourning, as well as parental spirituality, plus life goals and values for promoting child and family well-being.

\section{Measuring Religion and Health}

The final theme running through this issue relates to various measures utilized for considering and/or establishing evidence with respect to religion and health. The variety and utilization of instruments for considering religiosity and/or spirituality are increasingly diverse. This JORH issue considers various instruments covering religious/spiritual coping, self-efficacy, ethicotherapy, religious belief and action, and ultimately, spiritual/religious experience. Overall, these studies involve cohorts from China, Chile, Czech, England, Morocco, Poland, Slovakia, Iran and the USA.

Lastly, and certainly by no means least, there is the inclusion of a valuable study which considers data gathered via various culturally validated versions of the NERSH Questionnaire creating the International NERSH data pool of health professionals' attitudes toward religiosity and spirituality (Hvidt et al. 2016). The NERSH study 
presented in JORH covers the largest number of countries thus far in one exploration, namely Austria, Brazil, Congo, Denmark, Germany, India, Indonesia, New Zealand, Saudi Arabia, South Korea, Switzerland and the USA. The NERSH data collection uniquely enables researchers to study multifaith, cross-cultural, and international perspectives of health professionals regarding religiosity and spirituality. This is a significant development which will hopefully be utilized beyond the medical profession to also include allied health professionals who are increasingly aware of the importance of religion and health (Carey and Mathisen 2018).

\section{Coming Issues: 2021}

As noted in the previous editorial, the topic of moral injury (both military and civilian) has been gaining increasing recognition particularly from a religious/spiritual perspective (Carey and Hodgson 2018). Further, this year marks two decades since that devastating event of September 11. Authors are encouraged to consider these topics for submissions to JORH.

L. B. Carey

JORH Editor in Chief

\section{References}

Carey, L. B. (2020). COVID-19, aged care, cancer, medical research and mental health. Journal of Religion and Health, 59(6), 2667-2670. https://doi.org/10.1007/s10943-020-01127-z.

Carey, L. B., \& Hodgson, T. J. (2018). Chaplaincy, spiritual care and moral injury: Considerations regarding screening and treatment. Frontiers in Psychiatry, 9(619), 1-10. https://doi.org/10.3389/fpsyt .2018 .00619 .

Carey, L. B., \& Mathisen, B. A. (2018). Spiritual care for allied health practice: A person-centred approach. London: Jessica Kingsley Publishers. ISBN: 978-1-78450-501-1.

Grossoehme, D. H., Ragsdale, J. R., McHenry, C. L., Thurston, C., DeWitt, T., \& Vandecreek, L. (2007). Pediatrician characteristics associated with attention to spirituality and religion in clinical practice. Pediatrics, 119(1), e117-e123. https://doi.org/10.1542/peds.2006-0642.

Hvidt, N. C., Kappel Kørup, A., Curlin, F. A., Baumann, K., Frick, E., Søndergaard, J., et al. (2016). The NERSH international collaboration on values, spirituality and religion in medicine: Development of questionnaire, description of data pool and overview of pool publications. Religions, 7(8), 107-133. https://doi.org/10.3390/rel7080107.

JORH. (2020a). Journal of Religion and Health, 59(5). New York: Springer Nature. Retrieved November 30, 2020 from https://link.springer.com/journal/10943/volumes-and-issues/59-5.

JORH. (2020b). Journal of Religion and Health, 59(6). New York: Springer Nature. Retrieved November 30, 2020 from https://link.springer.com/journal/10943/volumes-and-issues/59-6.

JORH. (2021). Journal of Religion and Health, 60(1). New York: Springer Nature. https://link.springer.com/ journal/10943/volumes-and-issues/60-1.

Morgan, R. (2017). Image of Professions Survey 2017. Melbourne: Roy Morgan Market Research.

Nash, S., Nash, P., \& Darby, K. (2015). Spiritual care with sick children and young people: A handbook for chaplains, paediatric health professionals, arts therapists and youth workers. London: Jessica Kingsley Publishers. ISBN: 978-1-78450-063-4.

Reinhart, R. J. (2020). Nurses continue to rate highest in honesty, ethics. Washington, DC: Gallup News.

SCOPUS. (2020). 'COVID-19'. Scopus Data Base. Amsterdam: Elsevier. 
Publisher's Note Springer Nature remains neutral with regard to jurisdictional claims in published maps and institutional affiliations. 